\title{
Performance of Platinum Nanoparticles / Multiwalled Carbon Nanotubes / Bacterial Cellulose Composite as Anode Catalyst for Proton Exchange Membrane Fuel Cells
}

\author{
Henry Fonda Aritonang1*), Vanda Selvana Kamu², C. Ciptati ${ }^{3}$, Djulia Onggo ${ }^{4}$, \\ Cynthia L. Radiman ${ }^{4}$
}

\begin{abstract}
${ }^{1}$ Physical Chemistry Division, Faculty of Mathematics and Natural Sciences, Sam Ratulangi University, Kampus Unstrat Kleak, Manado 95115, Indonesia

${ }^{2}$ Organic Chemistry Division, Faculty of Mathematics and Natural Sciences, Sam Ratulangi University, Kampus Unsrat Kleak, Manado 95115, Indonesia

${ }^{3}$ Organic Chemistry Division, Faculty of Mathematics and Natural Sciences, Institut Teknologi

Bandung, Jln. Ganesha 10, Bandung 40132, Indonesia

${ }^{4}$ Inorganic and Physical Chemistry Division, Faculty of Mathematics and Natural Sciences, Institut Teknologi Bandung, Jln. Ganesha 10, Bandung 40132, Indonesia
\end{abstract}

Received: 21 ${ }^{\text {st }}$ November 2016; Revised: $26^{\text {th }}$ February 2017; Accepted: 27th February 2017

\begin{abstract}
Highly dispersed platinum (Pt) nanoparticles / multiwalled carbon nanotubes (MWCNTs) on bacterial cellulose (BC) as anode catalysts for proton exchange membrane fuel cells (PEMFC) were prepared with various precursors and their electro-catalytic activities towards hydrogen oxidation at $70{ }^{\circ} \mathrm{C}$ under non-humidified conditions. The composite was prepared by deposition of $\mathrm{Pt}$ nanoparticles and MWCNTs on BC gel by impregnation method using a water solution of metal precursors and MWCNTs followed by reducing reaction using a hydrogen gas. The composite was characterized by using TEM (transmission electron microscopy), EDS (energy dispersive spectroscopy), and XRD (X-ray diffractometry) techniques. TEM images and XRD patterns both lead to the observation of spherical metallic Pt nanoparticles with mean diameter of $3-11 \mathrm{~nm}$ well impregnated into the $\mathrm{BC}$ fibrils. Preliminary tests on a single cell indicate that renewable $\mathrm{BC}$ is a good prospect to be explored as a membrane in fuel cell field. Copyright (C) 2017 BCREC Group. All rights reserved
\end{abstract}

Keywords: Anode catalyst; Platinum nanoparticles; Multiwalled carbon nanotubes; Bacterial cellulose; Proton exchange membrane fuel cell

How to Cite: Aritonang, H.F., Kamu, V.S., Ciptati, C., Onggo, D., Radiman, C.L. (2017). Performance of Platinum Nanoparticles / Multiwalled Carbon Nanotubes / Bacterial Cellulose Composite as Anode Catalyst for Proton Exchange Membrane Fuel Cells. Bulletin of Chemical Reaction Engineering \& Catalysis, 12 (2): 287-292 (doi:10.9767/bcrec.12.2.803.287-292)

Permalink/DOI: http://dx.doi.org/10.9767/bcrec.12.2.803.287-292

\section{Introduction}

Proton exchange membrane fuel cells (PEMFC) are costly electrochemical energy conversion devices, but they are receiving

*) Corresponding Author

E-mail: henryaritonang@yahoo.com (Aritonang, H.F) increasing attention due to their environmentally friendly characteristics [1-2]. The PEMFC produces electricity as long as the fuel (usually hydrogen) and oxidant (usually oxygen) are supplied continuously to the respective anode and cathode. Pure water is the only by-product of PEMFC. The efficiency of energy conversion in 
PEMFC is dependent on the catalytic activities of the catalysts used in the cathode and anode of membrane electrode assemblies (MEAs). MEAs are considered the heart of PEMFC without which they cannot produce electricity. A typical method of making the MEA is hot pressing catalyst layers onto polymer electrolyte membranes (PEMs) [3-4]. The catalyst layers are prepared separately by painting, spraying or printing catalyst inks containing catalyst particles and polymer electrolyte suspension on the surface of carbon electrodes (gas diffusion layers, GDL). GDL with catalyst particles are used for both anode and cathode, and with either carbon or metal interconnects. The most commonly used catalyst in PEMFC are platinum (Pt)-based metals supported on high surface area carbon [5-6]

Yang et al. [7] have developed alternative new hydrocarbon-based polymer membranes that are bacterial cellulose (BC). The electrode used was BC coated Pt catalyst and carbon by way of brushing, and Pt catalyst performance has been analyzed with the PEMFC. Meanwhile, Aritonang et al. [8] have been coating BC by immersion into a solution of $\mathrm{Pt}$ precursors and carbon powder. The results showed that the $\mathrm{Pt}$ nanoparticles and carbon trapped in pores and spread evenly on the fibers of BC. The immersion method is more effective because it does not require much time, but the performance of $\mathrm{Pt}$ and carbon powder on $\mathrm{BC}$ membrane as the catalyst has not been done.

This paper reported that highly dispersed $\mathrm{Pt}$ nanoparticles are impregnation deposited by reduction method on the surface of $\mathrm{BC}$ (followed by insertion of MWCNTs on the BC surface). In addition, the electro catalytic activity of $\mathrm{Pt} / \mathrm{MWCNT} \mathrm{s} / \mathrm{BC}$ anode for hydrogen oxidation is also investigated. Therefore, the purpose of this study was to analyze the performance of $\mathrm{Pt}$ nanoparticles on a composite $\mathrm{Pt} / \mathrm{MWCNT} / \mathrm{BC}$ as a catalyst in hydrogen fuel cells.

\section{Materials and Methods}

\subsection{Materials}

Platinum tetrachloride $\left(\mathrm{PtCl}_{4}\right)$, potassium tetrachloroplatinate (II) $\left(\mathrm{K}_{2} \mathrm{PtCl}_{4}\right)$, and $5 \mathrm{wt} \%$ Nafion ${ }^{\circledR}$ solution were obtained from SigmaAldrich (99,9\%), while ammonium sulfate $\left[\left(\mathrm{NH}_{4}\right)_{2} \mathrm{SO}_{4}\right]$, glacial acetic acid $\left(\mathrm{CH}_{3} \mathrm{COOH}\right)$, hydrochloric acid $(\mathrm{HCl})$, sodium hydroxide $(\mathrm{NaOH})$, ethanol $\left(\mathrm{CH}_{3} \mathrm{CH}_{2} \mathrm{OH}\right)$, cetyltrimethylammonium bromide (CTAB), Nafion ${ }^{\circledR} 117$ (Dupont), 5\% hydrogen peroxide $\left(\mathrm{H}_{2} \mathrm{O}_{2}\right)$, were obtained from Merck. Carbon electrode (cathode catalyst as $20 \% \mathrm{Pt} / \mathrm{C}$ ) from Johnson Matthey, MWCNTs with outer diameters of 8$15 \mathrm{~nm}$, length $\sim 50 \mu \mathrm{m}$ and purity of $>95 \%$ was purchased from He Ji Limited Company, Hongkong. Hydrogen gas (ultra highly pure) was obtained from a local supplier. Coconut water, sucrose (food-grade white sugar) and Acetobacter xylinum were obtained from a local traditional market. All chemicals were used without further purification.

\subsection{Preparation of $\mathrm{Pt}$ nanoparticles MWCNTs / BC}

Preparation of BC was carried out as described previously by Radiman \& Yuliani [9]. To obtain dry BC membranes, the BC gel was first cut to a size of $4 \mathrm{~cm} \times 4 \mathrm{~cm}$, then pressed to remove water and finally air dried at room temperature for 6 days. MWCNTs were dispersed in deionized water with a cationic surfactant, cetyltrimethylammoniumbromide $(0.1$ wt \%). Ultrasound was applied to obtain a homogeneous dispersion using an ultrasonic generator (Bransonic ${ }^{\circledR}$ 2510E-DTH) for $2 \mathrm{~h}$ at $25{ }^{\circ} \mathrm{C}$.

The pressed BC membrane was soaked in aqueous a solution containing $20 \mathrm{mM} \mathrm{PtCl}_{4}$ and sonicated at room temperature for $2 \mathrm{~h}$. The BC gel was removed, rinsed with deionized water and soaked again in a MWCNTs solution and sonicated at room temperature for another $2 \mathrm{~h}$. The $\left[\mathrm{PtCl}_{4}\right] / \mathrm{MWCNTs} / \mathrm{BC}$ gel was removed, rinsed with deionized water and soaked in deionized water and then pressed to remove water and to obtain the dry composite membrane. The membrane was then reduced with hydrogen gas at an applied constant pressure of $0.5 \mathrm{psi}$ and a stirring speed of $500 \mathrm{rpm}$ at room temperature for $1 \mathrm{~h}$. The Pt-MWCNTs$\mathrm{BC}$ gel was removed from the solution and dried, as in the above procedure, and produced a dry composite that is denoted by $\mathrm{PtPtCl}^{-}$ MWCNTs-BC. The same procedure was carried out using $\mathrm{K}_{2} \mathrm{PtC}_{4}$ and $\mathrm{H}_{2} \mathrm{PtCl}_{6}$ precursor and composites derived were designated as $\mathrm{Pt}_{\mathrm{K} 2 \mathrm{PtCl}_{4} / \mathrm{MWCNT} / \mathrm{BC} \text { and }}$ $\mathrm{Pt}_{\text {H2PtCl6/MWCNTs/BC. }}$

\subsection{Physical characterization}

X-ray diffraction spectra were recorded using PW1835 Philips diffractometer (Japan) at $40 \mathrm{kV}$ and $30 \mathrm{~mA}$. The $2 \theta$ angular regions between 5 and $90^{\circ}$ were explored at a scan rate of $0.020 \%$ sec. Transmission electron microscopy (TEM) images were recorded using a JEOL JEM-1400(Japan) operating at $120 \mathrm{~V}$ and an acceleration voltage of $15 \mathrm{kV}$. For TEM measure- 
ments, composites were heated at $600{ }^{\circ} \mathrm{C}$ degrees to remove $\mathrm{BC}$. The residue formed by $\mathrm{Pt}$ nanoparticles was suspended in ethanol. A drop of the suspension was deposited on the copper grid. The information was added in the text. The particle sizes of the Pt nanoparticles were measured using Image $\mathrm{J}$ software. At least 200 particles of each sample from different TEM images were analyzed. The histogram of the size distribution was established by Origin software.

\subsection{Single cell tests}

Single-cell PEMFC performance of the composites was evaluated by a fuel cell test station. The anode and cathode material were composite and carbon paper that was coated with $20 \% \mathrm{Pt} / \mathrm{C}$, respectively. The composites were dripped with 1 drop of 5 wt\% Nafion ${ }^{\circledR}$ solution and dried at room temperature. Nafion ${ }^{\circledR} 117$ membrane was used as a polymer electrolyte membrane. Nafion ${ }^{\circledR} 117$ membrane was preconditioned prior to fabrication of membrane electrode assembly (MEA) to remove impurities. First, Nafion ${ }^{\circledR} 117$ membrane was boiled in $5 \%$ hydrogen peroxide at $80{ }^{\circ} \mathrm{C}$. Then, it was boiled in $0.5 \mathrm{M} \mathrm{H}_{2} \mathrm{SO}_{4}$ at $80{ }^{\circ} \mathrm{C}$ to let protons change to a form of hydrogen ion. Finally, the treated membranes were stored in aquadest prior to use [10].

The MEA obtained was mounted in a single cell with stainless steel end plates and graphite collector plates, which was designed with parallel ribbed channels for gas manifold. The MEA was fabricated by sandwiching the Nafion ${ }^{\circledR} 117$ membrane between the anode and cathode by hot pressing at $90{ }^{\circ} \mathrm{C}$ and 0.1 ton for $180 \mathrm{~s}$. The active cell area and thickness were 1 $\mathrm{cm}^{2}\left(1 \times 1 \mathrm{~cm}^{2}\right)$ and $0.28 \mathrm{~mm}$, respectively. The fuel cell testing is carried out at 1 atmospheric pressure and operating temperature of $70{ }^{\circ} \mathrm{C}$ with pure hydrogen and oxygen gas reactants.

\section{Results and Discussion}

\subsection{XRD, TEM, and EDX analysis of the Pt/ MWCNTs/BC membranes}

Figure 1 shows the powder X-ray diffraction patterns of the Pt/MWCNTs/BC membranes. All the composites exhibited four characteristic diffraction peaks of $\mathrm{Pt}$ at $2 \theta$ values around $40^{\circ}$, $46^{\circ}, 68^{\circ}$, and $81^{\circ}$ corresponding to the (111), (200), (220), and (311) planes, respectively. These peaks indicated that $\mathrm{Pt}$ is present in the face-centered cubic (fcc) structure (nearly identical to the standard values ICSD number 76951). The broad diffraction peaks of $\mathrm{Pt}$ in the composites are indicative of the nanosized Pt.

The average crystallite size of Pt supported on BC membrane is calculated from line broadening of the (200) diffraction peak (Gaussian-Lorentzian peak) according to Scherrer's equation $L=(0.9 \lambda) /(B \cos \theta)$, where $\lambda$ is the wavelength of the X-ray (1.5406 $\AA$ ), $\theta$ is the angle at the position of the peak maximum, and $B$ is the width (in radians) of the diffraction peak at half height [11]. The measured $\mathrm{Pt}$ crystallite size in the $\mathrm{PtPtCl}_{\mathrm{P}} / \mathrm{MWCNTs} / \mathrm{BC}$,

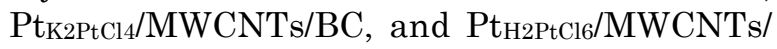
$\mathrm{BC}$ composite is $3.4,11.3$, and $6.9 \mathrm{~nm}$, respectively. Besides diffraction peaks of Pt, there are also threes characteristic diffraction peaks of $\mathrm{BC}$ around $14^{\circ}, 17$, and $22^{\circ}$. BC peaks appeared on the Pt/MWCNTs/BC composite and similar to $\mathrm{BC}$ membrane itself. Meanwhile, the peak of MWCNTs did not appear on the third composites because it has been covered by $\mathrm{Pt}$ particles.

Figure 2 shows the TEM images of the Pt nanoparticles. The size and size distribution of the Pt nanoparticles formed on the different precursors were analyzed by using TEM, and the histogram based on the TEM images illustrated their average size and size distribution. As seen in the figures, the Pt nanoparticles formed in every test composites exhibited a small size and a narrow size distribution. However, few Pt agglomerations are observed from $\mathrm{K}_{2} \mathrm{PtCl}_{4}$ and $\mathrm{H}_{2} \mathrm{PtCl}_{6}$ precursor. The data on particle size distribution revealed the presence of $\mathrm{Pt}$ nanoparticles in size range of $2-38 \mathrm{~nm}$, with an average size of 3,11 , and $6 \mathrm{~nm}$ from the $\mathrm{PtCl}_{4}, \mathrm{~K}_{2} \mathrm{PtCl}_{4}$, and $\mathrm{H}_{2} \mathrm{PtCl}_{6}$ precursor, respectively. The data show that the size of $\mathrm{Pt}$

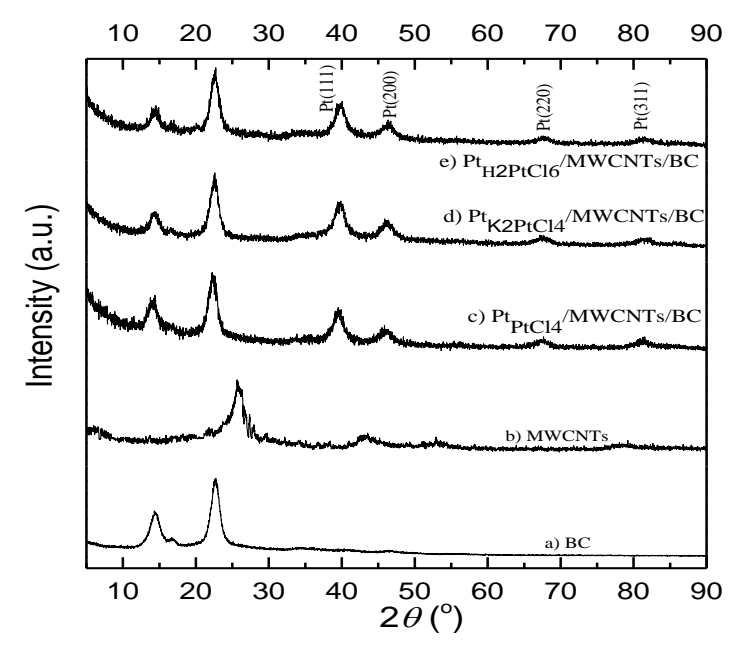

Figure 1. XRD patterns of a) BC, b) MWCNTs, c) $\mathrm{PtPtCl}_{\mathrm{P}} / \mathrm{MWCNTs} / \mathrm{BC}$, d) $\mathrm{Pt}_{\mathrm{K} 2 \mathrm{PtCl}} / \mathrm{MWCNTs} /$ $\mathrm{BC}$, and e) $\mathrm{Pt}_{\mathrm{H} 2 \mathrm{PtCl}} / \mathrm{MWCNT} / \mathrm{BC}$ composite 
nanoparticle from $\mathrm{PtCl}_{4}$ precursor is relatively smaller than other precursors with narrower particle size distribution $(\sigma)$.

The particle sizes measured from TEM images are almost comparable with those of the crystallite sizes determined from XRD. It indicates the existence of $\mathrm{Pt}$ particles as single crystallites on $\mathrm{BC}$ membrane support. The average sizes of the $\mathrm{Pt}$ nanoparticles of all the precursors calculated from the XRD peak widths agreed well with the TEM results. The morphological data of all the Pt nanoparticles are presented in Table 1. The surface areas of these $\mathrm{Pt}$ catalysts are calculated from the mean diameter of the particles obtained from the
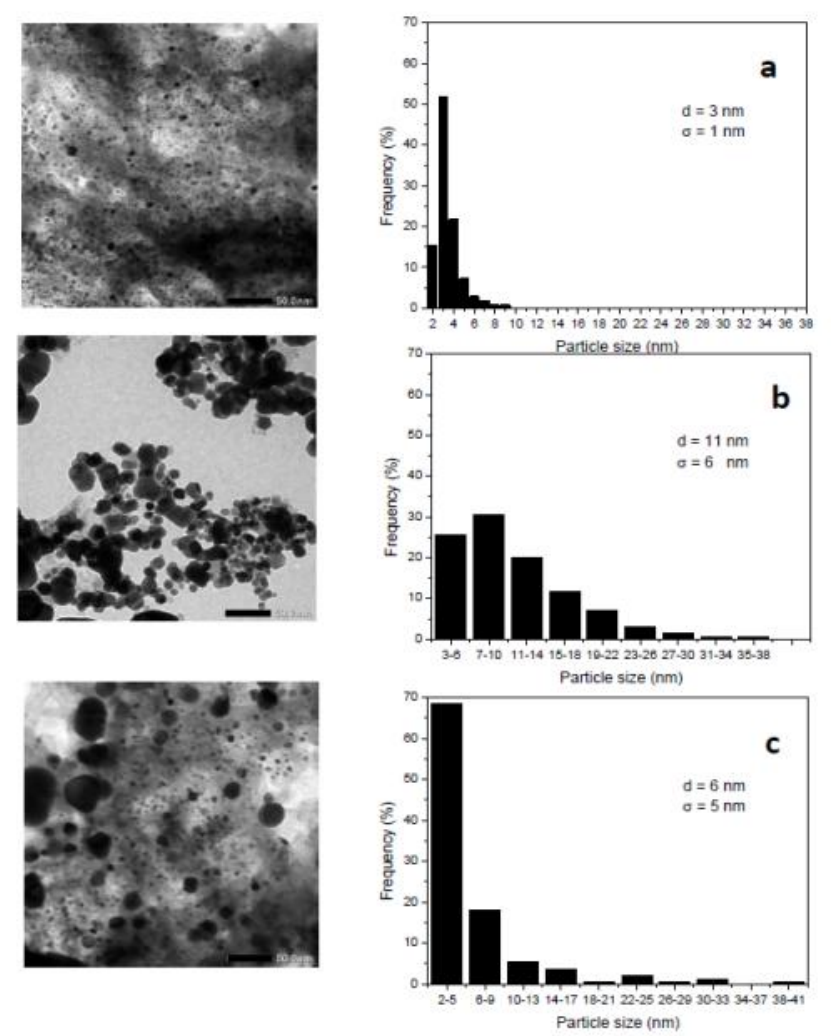

Figure 2. TEM images and particle size distribution histograms of $\mathrm{Pt}$ nanoparticles formed in $\mathrm{BC}$ membranes prepared from $\mathrm{PtCl}_{4}$ (a), $\mathrm{K}_{2} \mathrm{PtCl}_{4}$ (b) and $\mathrm{H}_{2} \mathrm{PtCl}_{6}$ (c) as the precursor source
TEM images by using the equation:

$$
S=6000 / d \rho
$$

where $\rho$ is the Pt density $\left(21.45 \mathrm{~g} / \mathrm{cm}^{3}\right), d$ is the particle size (in $\mathrm{nm}$ ) [12]. Among all the $\mathrm{Pt}$ nanoparticles, the surface area is found to be the largest for the $\mathrm{Pt}$ from $\mathrm{PtCl}_{4}$ precursor because of its smaller particle size with good dispersion on the $\mathrm{BC}$ membrane.

By EDS investigation, the Pt content was tested to the composite and composition of $\mathrm{Pt}$ are presented in Table 1. The data show that the content of the $\mathrm{Pt}$ particles is derived from $\mathrm{PtCl}_{4}$ precursor relatively more than those from other precursors. The measurement of $\mathrm{Pt}_{\mathrm{PtCl}} / \mathrm{MWCNTs} / \mathrm{BC}$ composite was taken as an example and is demonstrated in Figure 3.

\subsection{Fuel cell performance}

Figure 4 compares the performance of the PEMFC at $70 \circ \mathrm{C}$ using $\mathrm{Pt}$ catalyst on the $\mathrm{Pt} / \mathrm{MWCNT}$ s/BC composite as the anode under the same testing conditions. The results showed that $\mathrm{Pt}$ nanoparticles contained in the composite anode of $\mathrm{Pt} / \mathrm{MWCNT} / \mathrm{BC}$ could serve as a catalyst for the oxidation of hydrogen. This can be seen in the performance profile of Pt on PEMFC for each electrode, which is expressed in a curve polarization current $(I)$ of the potential $(V)$ and power $(W)$, which is
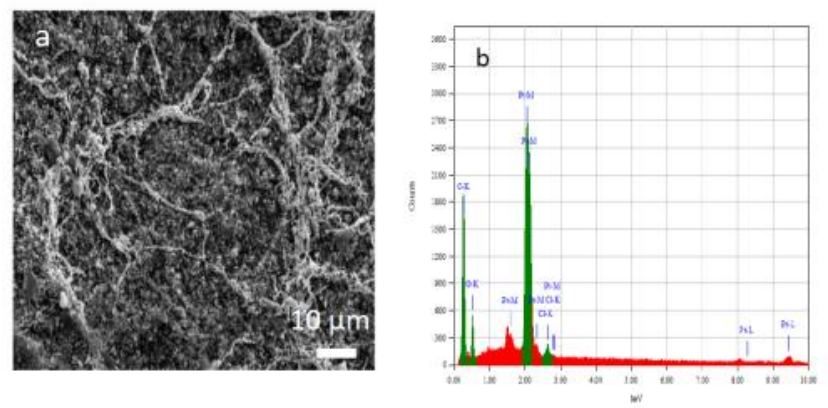

Figure 3. Typical SEM image (a) and the corresponding EDS pattern (b) of the $\mathrm{Pt}_{\mathrm{PtCl} 4} / \mathrm{MWCNTs} / \mathrm{BC}$ membrane

Table 1. EDX composition and comparison of morphological data of the Pt nanoparticles prepared at different precursors on composites

\begin{tabular}{lcccc}
\hline \multicolumn{1}{c}{ Composites } & $\begin{array}{c}\text { EDX composi- } \\
\text { tion of Pt }\end{array}$ & $\begin{array}{c}\text { Particle size from } \\
\text { TEM }(\mathrm{nm})\end{array}$ & $\begin{array}{c}\text { Particle size from } \\
\text { XRD }(\mathrm{nm})\end{array}$ & $\begin{array}{c}\text { Surface Area } \\
\left(\mathrm{m}^{2} \mathrm{~g}-1\right)\end{array}$ \\
\hline $\mathrm{Pt}_{\mathrm{PtCl} 1} / \mathrm{MWCNTs} / \mathrm{BC}$ & 51.43 & 3 & 3.4 & 93.24 \\
$\mathrm{Pt}_{\mathrm{K} 2 \mathrm{PtCl}} / \mathrm{MWCNT} / \mathrm{BC}$ & 29.77 & 11 & 8.3 & 25.43 \\
$\mathrm{Pt}_{\mathrm{H} 2 \mathrm{PtCl}} / \mathrm{MWCNT} / \mathrm{BC}$ & 47.01 & 6 & 5.2 & 46.62 \\
\hline
\end{tabular}


carried out at a temperature of $70^{\circ} \mathrm{C}$.

The performance of anode shows that maximum power density for three composites (electrode) are different. At $0.07 \mathrm{~V}$, Pt catalyst on the $\mathrm{Pt}_{\mathrm{PtCl}} / \mathrm{MWCNTs} / \mathrm{BC}$ composite yielded a current density and power density are 1.94 mA.cm ${ }^{-2}$ and 0.13 mW.cm ${ }^{-2}$, respectively. Meanwhile, other composite showed that a much lower value, as shown in Table 2 .

PEMFC performance using composite anodes showed patterns similar profiles for all of the electrodes, but it has optimum peak power density of different. When using the $\mathrm{Pt}_{\left(\mathrm{K} 2 \mathrm{PtCl}_{4}\right)} / \mathrm{MWCNTs} / \mathrm{BC}$ electrode, the performance of $\mathrm{Pt}$ on PEMFC produces optimum peak power density of $0.02 \mathrm{~mW} / \mathrm{cm}^{2}$ at current densities of $0.60 \mathrm{~mA} / \mathrm{cm}^{2}$, while using $\mathrm{Pt}_{(\mathrm{H} 2 \mathrm{PtCl} 6)} / \mathrm{MWCNT}$ s/BC electrode, the optimum power density of $0.03 \mathrm{~mW} / \mathrm{cm}^{2}$ at current density of $0.30 \mathrm{~mA} / \mathrm{cm}^{2}$ and using $\mathrm{Pt}_{(\mathrm{PtCl} 4)} / \mathrm{MWCNTs} / \mathrm{BC}$ electrode, optimum power density of $0.11 \mathrm{~mW} / \mathrm{cm}^{2}$ at current densities of

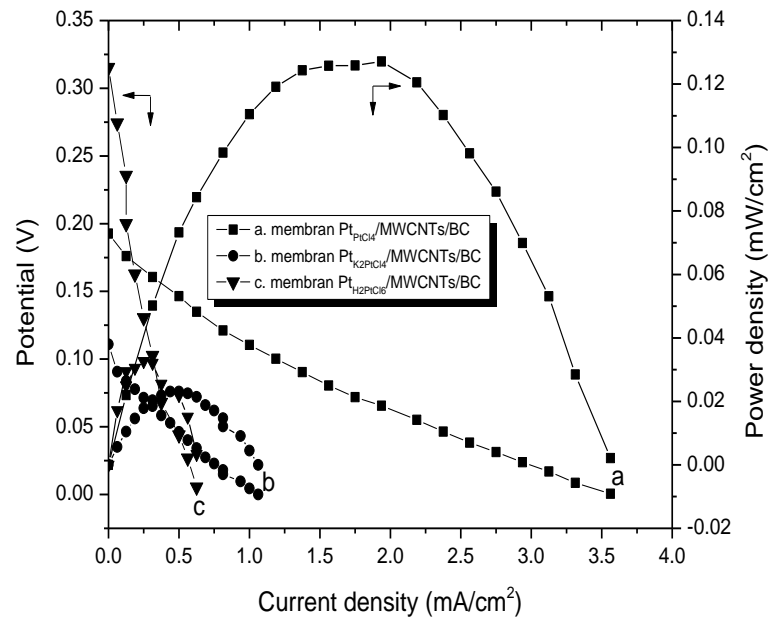

Figure 4. Comparison of single cell polarization curves for the PEMFC in presence of

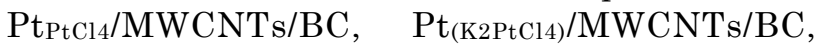
$\mathrm{Pt}_{(\mathrm{H} 2 \mathrm{PtCl} 6)} / \mathrm{MWCNT} / \mathrm{BC}$ anode catalysts; cathode: Pt/C (20 wt.\%, Johnson Matthey Corp.); electrolyte membrane: Nafion-117®(DuPont) membranes; operation temperature: $70{ }^{\circ} \mathrm{C}$

\section{$2.10 \mathrm{~mA} / \mathrm{cm}^{2}$.}

Optimum power density generated by the $\mathrm{Pt}_{(\mathrm{PtCl})} / \mathrm{MWCNTs} / \mathrm{BC}$ electrode larger than the other electrode. This is due to the high content of Pt nanoparticles contained in the electrode. In addition, the size distribution of Pt nanoparticles smaller than $\mathrm{PtCl}_{4}$ precursor sources, have an impact on current density and optimum power greater than the $\mathrm{Pt}$ nanoparticles from other Pt precursor sources. This is because the particle size distribution of Pt affects the course of the oxidation reaction of hydrogen [13].

This performance difference in the activation region can be attributed mainly to the difference in the $\mathrm{Pt}$ particle size between on the $\mathrm{Pt}_{\mathrm{PtCl} 4} / \mathrm{MWCNT} / \mathrm{BC}$ (3 nm), $\mathrm{Pt}_{\mathrm{K} 2 \mathrm{PtCl}_{4} /} /$ MWCNTs/BC (11 nm), and $\mathrm{Pt}_{\mathrm{H} 2 \mathrm{PtCl}} / \mathrm{MWCNTs} /$ $\mathrm{BC}(6 \mathrm{~nm})$ composite. In addition, the content of $\mathrm{Pt}$ on the composite can also affect the cell performance [14]. Furthermore, in the ohmic polarization region, the cell performance using $\mathrm{Pt}_{\mathrm{K} 2 \mathrm{PtCl} 4} / \mathrm{MWCNTs} / \mathrm{BC}$ and $\mathrm{Pt}_{\mathrm{H} 2 \mathrm{PtCl} 6} / \mathrm{MWCNT}$ s/ $\mathrm{BC}$ composites are also lower than that using the $\mathrm{Pt}_{\mathrm{PtCl}} / \mathrm{MWCNTs} / \mathrm{BC}$ composite.

\section{Conclusion}

The performance of a PEMFC is studied with Pt/MWCNTs/BC composite and Pt black catalysts as anode and cathode catalysts, respectively. The effect of $\mathrm{Pt}$ size as a catalyst on composite is studied. The $\mathrm{Pt}_{\mathrm{PtCl}} / \mathrm{MWCNTs} / \mathrm{BC}$ composite is seen to give the best performance for a PEMFC when used as an anode catalyst because the size of $\mathrm{Pt}$ particle, size distribution and $\mathrm{Pt}$ content on composite are smaller, narrow size and more content, respectively than other precursors.

\section{References}

[1] Lister, S., McLean, G. (2004). Review PEM fuel cell electrodes. Journal of Power Sources, 130: $61-76$

[2] Carrette, L., Friedrich, K.A., Stimming, U. (2001). Fuel Cells, Fundamentals and Applications. Fuel Cells, 1: 5-39.

Table 2. Comparison of potential, current density, and optimum power density using different composite anode

\begin{tabular}{|c|c|c|c|c|c|c|c|c|}
\hline \multicolumn{3}{|c|}{$\mathrm{Pt}_{\mathrm{PtCl} 4} / \mathrm{MWCNTs} / \mathrm{BC}$} & \multicolumn{3}{|c|}{$\mathrm{Pt}_{\mathrm{K} 2 \mathrm{PtCl} /} / \mathrm{MWCNTs} / \mathrm{BC}$} & \multicolumn{3}{|c|}{$\mathrm{Pt}_{\mathrm{H} 2 \mathrm{PtCl} 6} / \mathrm{MWCNTs} / \mathrm{BC}$} \\
\hline $\begin{array}{l}\text { Poten- } \\
\text { tial } \\
\text { (V) }\end{array}$ & $\begin{array}{c}\text { Current } \\
\text { density } \\
\left(\mathrm{mA} / \mathrm{cm}^{2}\right)\end{array}$ & $\begin{array}{c}\text { Power } \\
\text { density } \\
\left(\mathrm{mW} / \mathrm{cm}^{2}\right)\end{array}$ & $\begin{array}{c}\text { Poten- } \\
\text { tial } \\
\text { (V) }\end{array}$ & $\begin{array}{c}\text { Current } \\
\text { density } \\
\left(\mathrm{mA} / \mathrm{cm}^{2}\right)\end{array}$ & $\begin{array}{c}\text { Power } \\
\text { density } \\
\left(\mathrm{mW} / \mathrm{cm}^{2}\right)\end{array}$ & $\begin{array}{c}\text { Poten- } \\
\text { tial } \\
\text { (V) }\end{array}$ & $\begin{array}{c}\text { Current } \\
\text { density } \\
\left(\mathrm{mA} / \mathrm{cm}^{2}\right)\end{array}$ & $\begin{array}{c}\text { Power } \\
\text { density } \\
\left(\mathrm{mW} / \mathrm{cm}^{2}\right)\end{array}$ \\
\hline 0.07 & 1.94 & 0.13 & 0.05 & 0.60 & 0.02 & 0.07 & 0.30 & 0.03 \\
\hline
\end{tabular}


[3] Haile, S.M. (2003): Fuel Cell Materials and Components. Acta Materialia, 51: 5981-6000.

[4] Hickner, M.A., Pivovar, B.S. (2005). The Chemical and Structural Nature of Proton Exchange Membrane Fuel Cell Properties. Fuel Cells, 5: 213-229.

[5] Yuan, X.Z., Wang, H. (2008). PEM Fuel Cell Fundamentals. In: Zhang, J. (ed). PEM Fuel Cell Electrocatalysts and Catalyst Layers Fundamentals and Applications. Canada: Springer-Verlag London Limited; 2008. pp. 187.

[6] Holton, O.T., Stevenson, J.W. (2013). The Role of Platinum in Proton Exchange Membrane Fuel Cells. Platinum Metals Review, 57: 259-271.

[7] Yang, J., Sun, D., Li, J., Yang, X., Yu, J., Hao, Q., Liu, W., Liu, J., Zou, Z., Gu, J. (2009). In Situ Deposition of Platinum Nanoparticles on Bacterial Cellulose Membranes and Evaluation of PEM Fuel Cell Performance. Electrochimica Acta, 54: 6300-6305.

[8] Aritonang, H.F., Onggo, D., Ciptati, C., Radiman, C.L. (2015). Insertion of Platinum Particles in Bacterial Cellulose Membranes from $\mathrm{PtCl}_{4}$ and $\mathrm{H}_{2} \mathrm{PtCl}_{6}$ Precursors. Macromolecular Symposia, 353(1): 55-61

[9] Radiman, C.L., Yuliani, G. (2008). Coconut Water as a Potential Resource for Cellulose Acetate Membrane Preparation. Polymer International, 57: 502-508.
[10] Birry, L., Bock, C., Xue, X., McMillan, R., MacDougall, B. (2009). DMFC Electrode Preparation, Performance and Proton Conductivity Measurements. Journal of Applied Electrochemistry, 39: 347-360.

[11] Li, W., Liang, C., Zhou, W., Qiu, J., Zhou, Z., Sun, G., Xin, Q. (2003). Preparation and Characterization of Multiwalled Carbon Nanotube-Supported Platinum for Cathode Catalysts of Direct Methanol Fuel Cells. J. Phys. Chem. B, 107: 6292-6299

[12] Li, X., Qiu, X., Zhao, L., Chen, L., Zhu, W. (2009). Development of composite anode electro catalyst for direct methanol fuel cells. $J$ Appl. Electrochem., 39: 1779-1787

[13] Zhao, Y., Fan, L., Zhong, H., Li, Y. (2007). Electrodeposition and Electrocatalytic Properties of Platinum Nanoparticles on Multiwalled Carbon Nanotubes: Effect of The Deposition Conditions, Microchim. Acta, 158: 327-334.

[14] Aricò, A.S., Srinivasan, S., Antonucci, V. (2001). DMFCs: From Fundamental Aspects to Technology Development, Fuel Cells, 1: 133-161

Selected and Revised Papers from The 2nd International Seminar on Chemistry (ISoC 2016) (Surabaya, 26-27 July 2016) (http://chem.its.ac.id/isoc-2016/) after Peer-reviewed by Scientific Committee of ISoC 2016 and Peer-Reviewers of BCREC journal 